Submitted Version: Critical Review of International Social and Political Philosophy

http://dx.doi.org.libproxy.ucl.ac.uk/10.1080/13698230.2016.1183761

\title{
On the Logic of Productive Cooperation: A Response to Critics
}

\author{
Albert Weale \\ Department of Political Science \\ University College London \\ a.weale@ucl.ac.uk
}

\begin{abstract}
This paper identifies and responds to four critiques of democratic contractarianism, as advocated in Democratic Justice and the Social Contract, to be found in this symposium. The first is that, as a contingent practice-dependent account of justice, democratic contractarianism lacks the capacity to explain civic cooperation. The second is that, despite its intentions, Democratic Justice does not lay out an authentic contractarian theory. The third is that the theory is incompatible with our considered judgements about justice. And the fourth is that the ambition of Democratic Justice to use the empirical method to compensate for the failures of hypothetical contract theory fails because all social science needs interpretation. To each of these critiques replies are offered, drawing attention to the way in which democratic contractarianism exemplifies a logic of social cooperation to mutual advantage that is compatible with justice provided the cooperation emerges from a bargaining situation of roughly equal power.
\end{abstract}




\section{Keywords}

democracy; democratic contractarianism; justice; social contract;

\section{Word Count: 7719}

\section{Introduction}

There is something both daunting as well as flattering in a number of highly intelligent and well-informed critics scrutinizing one's work. I am grateful to the participants in this symposium for the care and attention that they have all given to reviewing Democratic Justice and the Social Contract (Weale, 2013), as well as for their willingness to participate in the workshop at LUISS in Rome on which the symposium is based. I am also grateful to Ian Carter, who waived his anonymity as a referee, for pressing some additional questions on me. And, of course, I owe a particular debt of gratitude to Valentina Gentile both for organizing the original meeting in highly congenial circumstances and for her editorial efforts ensuring that our joint labours came to publishing fruition.

Those who have read Democratic Justice will know that one of its underlying themes is that participants in a productive enterprise have both common interests in the supply of public goods that make the enterprise possible and competitive interests in the share of divisible goods that each can secure from the enterprise. In political theory the counterpart to this logic are the common interests that participants have in defining the themes for discussion, together with the different and mutually incompatible views about how those themes are to be understood and interpreted. This symposium exhibits that logic well. There is general agreement on what issues are central to the claims of Democratic Justice, alongside 
disagreement on how well the book copes with the challenges those issues raise. In particular, the contributors to this symposium raise four main questions. Firstly, what is the character of the theory being advanced? Secondly, how should we understand the theory as measured against the distinction between contractarian, or mutual advantage, theories of justice on the one hand, and contractualist, or impartialist, theories on the other? Thirdly, does democratic contractarianism issue in principles incompatible with considered judgements of justice? Finally, does the theory succeed in its ambition of providing a 'device of representation' - to use Rawls's (1996: 25; 2001: 80) term - based on empirical evidence that enables us to understand what justifiable principles of justice there might be? I shall discuss the contributions under each of these headings.

\section{The Character of the Theory}

Gentile (2016) suggests that democratic contractarianism is a 'contingent practice-dependent' account of justice by contrast with an 'institutional practice-dependent model' of the type associated with Rawls (1996). The theory is practice-dependent because it makes the specification of principles of justice dependent upon an account of democratic procedures in order define what the principles of justice are. In that sense, it makes politics prior to morality. It is contingent, rather than institutional, because it does not presuppose that the practice in question is informed by a moralized notion of citizenship.

I find very helpful Gentile's contrast between a contingent conception and an institutional conception, even if she and I differ as to the relative merits of the contrast. Remember that 'contingent' here means something like 'not presupposing the role-obligations of citizenship'. Rawls's theory of justice is an explication of the idea of society as a fair system of cooperation among free and equal citizens, as members of a well-ordered society, with the 
principles they agree in the original position governing the basic structure of their society (Rawls, 2001: 25). In that theory, the parties to the contract are assumed to have the two moral powers, namely a capacity for a conception of the good and a capacity for a sense of justice. By contrast, in Democratic Justice the process of contractual agreement is constructed with fewer moralized features. The parties are participants in an autonomous society who rely upon one another to preserve their common interests in the environment from which they earn their livelihoods. They are closer to Hume's (1739/40: 573) farmers who cannot agree on mutual aid in their harvesting, so jeopardizing the good of each, than they are, for example, to the idealized inhabitants of a Jeffersonian democracy with their abundant land ownership, with which Rawls's political philosophy has an intellectual affinity (Zhichao, 2015: 293-6).

Why might this non-moralized construction be attractive in a theory of justice? One answer is that it makes justice contingent on the practices that are needed to enable successful cooperation, without neglecting the fact that principles of justice are needed to regulated conflicts of interest. One central claim in Democratic Justice is that there is a basic logic of social cooperation captured in such a model that is revealed in a variety of cultural contexts. For example, the communities identified by Ostrom (1992) as having successful regimes of common property regimes are found in Switzerland, Spain, Turkey, the Philippines and Japan, meaning that they occur in very different cultural contexts. What induces cooperation is an enforced inter-dependence - for example the need to protect stocks of animals or plants - that none can avoid. It is this inter-dependence that creates the equality of power that is central to logic of democratic contractarianism.

Gentile argues that the construction of Democratic Justice is inadequate because it cannot account for the disposition to act justly that is underscored by the Rawlsian sense of justice. If all that individuals possess is a prudent, bounded and defeasible rationality, how will they 
be able to cooperate when opportunities arise for them to cheat or gain an advantage over others (compare Howard, 2015)? She illustrates this dilemma with a reconstructed example of an experiment carried out in Expo 2015 in Milan. In the example, a fixed stock of goods is made available to anyone who wishes to appropriate those goods in a limited period of time. Gentile concludes that in such situations rationally prudent individuals would not act cooperatively and the goods would be rapidly depleted. The dilemma can be resolved of an external set of incentives and sanctioning.

However, the lesson of common property resources regimes is that self-governing communities can themselves construct the rules and monitoring that are able to regulate to mutual advantage the access of individuals to harvestable resources. It is not simply a matter of prudent rationality. Institutions are required, based on the recognition that the cumulative consequences of individuals acting in an unconstrained way mean that each will be worse off than they need be. This is the logic of the prisoner's dilemma. This logic has been of particular interest to contractarians over a number of years. (Indeed, there is a case to be made that it goes back to the earliest known statement of justice as mutual advantage put into the mouth of Glaucon by Plato in Book II The Republic, see Denyer, 1983.) The fascination has not been through lack of imagination. Rather the prisoner's dilemma exemplifies an important paradox. What seems to be individually maximizing behaviour turns out in its collective consequence to be self-defeating for each actor. Each really would be better off by cooperating. A reflective prudent rationality would recognise this.

Gentile argues that the Rawlsian construction is superior because it shows how a just and stable order can come about for the right reasons, and in particular how compliance will be secured by individuals acting as citizens in roles that are specified in a regime of justice. Grant that, if individuals have the motives that Rawls ascribes to them, then they will act in compliance with Rawlsian principles. However, that is not the theoretical challenge that 
needs to be met. Rather what the Rawlsian needs to show is that only by attributing civic motives in the device of representation can we meet the challenge of compliance. But why can we not have a different and more naturalistic picture? We can imagine societies in which cooperative practices are established, and citizens understand the general advantage in participating in and abiding by such practices. Of course, they monitor one another to ensure that no one is taking undue advantage, and bounded rationality means that it is often not worth taking the trouble to find ways of getting around the rules on particular occasions. Indeed, citizens can cooperate with one another on just terms even if they do not like one another, as is indeed true of the inhabitants of Törbel, a successful common property resource regime (Netting, 1981: 186-7).

\section{Justice: Contractarian or Contractualist?}

Follesdal (2016) and Bufacchi (2016) advance separate but complementary arguments, seeking to confront the theory of democratic contractarianism with a dilemma. Either the theory is not genuinely contractarian, not really being based on the idea of mutual advantage because moralized premises are sneaked into the construction, or, if it is genuinely contractarian, then the theory has morally unattractive consequences that favour injustice rather than justice. In consequence, either one must give up democratic contractarianism's distinctive features, in order to safeguard the morally acceptable conclusions, or keep the distinctive theory and accept the unpalatable conclusions. If I accept the first criticism, then I have not avoided the faux constructivism that Matravers (2000: 100) alleged contractualists fell into. Matravers (2015) himself has claimed that this is a problem with Democratic Justice as did Ian Carter in his referee's report. 
To evaluate this line of criticism we need a definition of the distinction between contractarianism and contractualism. Follesdal's version is crisp and to the point (see also Castiglione, 2015). Contractarianism seeks to justify normative principles from a set of premises devoid of normative elements, relying solely on ideas of mutual advantage. Contractualism assumes that individuals are motivated by other-regarding moral considerations to agree on impartial principles of distributive justice. Follesdal lines up this distinction with two different purposes that a contract theory can serve. The first is the justification of morality to those who are prone to doubt its claims, an aim found in contractarianism. The second is the systematization of vague and contested normative judgements, an aim of contractualism.

Allowing that we can distinguish contractarianism from contractualism by reference to the role of moral propositions in the premises of the construction does not entail that each is associated with disjoint theoretical purposes. To be sure, contractualists like Barry and Scanlon think it a mistake to look for non-moral reasons to be moral, limiting their ambitions to Follesdal's clarificatory role. On the other hand, a contractarian like Gauthier advances both a theory of obligation and a theory of economic justice based on bargaining over the cooperative surplus. Democratic Justice in fact had a strong clarificatory objective, particularly in relation to competing principles of economic justice, although I hope the theory is consistent with an account of morality in which prudential rationality plays a central role in understanding the grounds of obligation. However, this point is relatively minor, since the main burden of Follesdal's critique is that I end up with a theoretical construction that is contrary to my own ambition to make the agreement on justice depend solely on the circumstances in which the contract is negotiated rather than the motives of the agents. In particular, he thinks I fall back into a faux constructivism by defining as just those social contracts emerging from initial situations of approximately equal power. 
To what extent is the invocation of an equal power condition contractarian? Here is one reason for thinking it so. Although the circumstances of bargaining among the parties are restricted to those that meet an equal power condition, there is no assumption that the parties are motivated by the sort of other-regarding considerations associated with contractualist thinking. For example, there is no 'agreement motive' of the sort posited by Brian Barry (1995: 164-8), or the desire for reasonable agreement of the sort supposed by Scanlon (1982: 111). Of course, in discussing justice a theorist is hoping to explicate a moral notion. However, there is a distinction between the terms that occur within the theoretical construction and the conception that the theoretical construction is seeking to explicate. An analogy may help to make this distinction clear. The first theorem of modern welfare economics is that every competitive equilibrium is also a Pareto optimum. However, it is not assumed in this theorem that there is a motivation on the part of each of the parties to achieve a Pareto optimum. Rather the theorem is a development of Adam Smith's famous observation that in preferring the support of domestic to that of foreign industry, the individual 'intends only his own gain, and he is in this, as in many other cases, led by an invisible hand to promote an end that was no part of his intention' (Smith, 1776: 456). The optimality of the equilibrium is explained without reference to the motivations of the parties. Indeed, even Rawls (1999: 103) thinks that this is one way of thinking about the device of representation in his own theory.

Follesdal also argues that, even if the moralized premises do not occur in the characterization of the motives of the agents, it is a fault that they appear in the characterization of the original position in which agents form a social contract. He writes: 'To remain a contractarian, Weale must offer a "non-moralized" rationale for identifying "a subset of political associations that satisfy, so far as possible, the circumstances that make it plausible to hold that the upshot of the negotiation is one of justice."' (Follesdal, 2016: 5). If not, I risk being a "closet 
contractualist, seeking to explicate and make our normative intuitions about justice more precise by the heuristic device of a social contract which expresses a commitment to political equality'.

One answer to this line of criticism is that I was seeking to locate Democratic Justice in a tradition of thinking about justice that goes back through the Epicureans and the Sophists to Glaucon's statement in Plato's Republic, Book II. In this way of thinking, the reciprocal ability of individuals to inflict harm on one another is central to the motivation to agree a social contract. A similar thought is to be found in Hobbes's (1651: 80) claim that persons are equal because 'the weakest has strength enough to kill the strongest'. In Democratic Justice I more than once cite John Stuart Mill (1869: 478) to the effect that the ancient republics had a law other than that of force because they were formed of a union of persons of not very unequal strength. Yet, although there is a tradition linking justice to equality of power, there is nothing self-evident in such a theory. Socrates thought unjust behaviour was a product of ignorance. The view that justice is defined by the results of a social contract among parties of roughly equal power is a conjecture to be developed and tested.

Bufacchi seeks to generalize Follesdal's line of criticism by noting Barry's view that the trouble with theories of justice as mutual advantage is that they carry over inequalities in the initial pre-contractual situation into outcomes arising as a result of the contract (see also Cordelli, 2015). It is problematic to use a baseline of non-cooperation as part of our reasoning about justice because to do so 'would give unfair bargaining advantages to some (the dominant party) over others (the vulnerable), therefore the outcome of the agreement would simply reflect the differences in bargaining advantages' (Bufacchi, 5). How far, however, does this criticism stand up? 
There are different versions of mutual advantage conceptions of justice. Some are consistent with the Hobbes's (1651: 85) assumption that in a pre-contractual state of nature, everyone has a right to everything 'even to one another's body'. Others impose some constraint on the character of the pre-contractual situation. In modern contract theory a clear example of Hobbesianism is James Buchanan's The Limits of Liberty in which there are no constraints on behaviour or endowments of individuals before a contract is agreed (Buchanan, 1975). A second type of mutual advantage thinking is one in which there are constraints on the interaction of the parties before the contract, as exemplified in the work of Gauthier. Gauthier assumes that prior to the contract of mutual advantage, agents respect a version of the Lockean proviso, according to which one agent, A, should not make another agent, B, worse off than B would have been without the presence of A (Gauthier, 1986: 200-8).

Democratic Justice can be located mid-way between Buchanan's theory and Gauthier's. It rejects Buchanan's assumption that in constructing a social contract theory any behaviour that takes advantage of superior strength is allowable in the original position, and that the only problem to deal with is the elimination of mutually harmful externalities. It rejects Gauthier's assumption that the right constraint on interaction in the pre-contractual situation is the Lockean proviso, holding instead that the existence of pervasive externalities means that it is inevitable that the co-existence of people will worsen the situation of each relative to what it would have been had those others not existed. In particular, for the democratic contractarian, pressure on resources may be such that no everyone can leave 'enough and as good' for everyone else.

In Democratic Justice relations among actors in the pre-contractual situation take the form of Hohfeld's (1923) liberties. That is to say, no one is under an obligation to allow another to appropriate a resource, given that no one's behaviour is constrained by the Lockean proviso. However, if someone has already appropriated a resource, then everyone else is under an 
obligation to respect that appropriation. Can one assume a regime of Hohfeldian liberties in a construction that makes justice derive from a contract to mutual advantage, however?

Hohfeldian liberties impose some negative obligations, and so seem incompatible with a nonmoralized approach to theory construction. Should one not be more Hobbesian? Interestingly, I have discovered, since writing Democratic Justice, that Vincent Ostrom (2012: 147), who sought to provide the underlying philosophy of social science for the programme he shared with Elinor Ostrom, read Hobbes with Hohfeld in mind. This may, of course, mean that the social science of common property resource regimes has got off on the wrong philosophical foot. However, there is another interpretation. Pure Hobbesian states of nature are rare, because their conditions are so inhospitable to any human life. Viable social orders, even unjust ones, require their participants to follow some rules of interaction if they are to survive. Minimally rule-governed human practices are a necessary condition for any continuing society, and the Hohfeldian assumption is one way of capturing this point.

Against this background assumption, Democratic Justice suggests that the principles of economic justice emerging from a social contract made under conditions of approximately equal power will be that productive agents keep the full fruits of their labour, noting that this choice is supported by the observation of common property resource regimes. The underlying logic here is not that of Nozickean 'self-ownership' or 'basic endowments', as Bufacchi thinks I must be driven to, but rather that of a focal point solution among many other possible rules that might occur to contracting parties seeking to impose mutual limits on the exercise of their Hohfeldian liberties (Weale, 2013: 72-8). Yet, as both Follesdal and Bufacchi note, the principle of producers retaining the full fruits of their labour precludes redistribution on grounds of need, and they urge that this rejection of the principle of need is incompatible with reflective and considered judgements of justice. In this they are joined by Andreozzi. This brings us to the third issue on the agenda. 


\section{Democratic Contractarianism and Our Considered Judgements}

Common property resource regimes are typically small scale and agricultural. Democratic Justice follows Hayek (1973) and ultimately Adam Smith (1776) in naming industrial and post-industrial societies 'great societies' (for an extension of this use, see O'Flynn, 2015). In such societies, the equivalent to the full fruits of labour principle is that producers secure their marginal product. For those whose productivity is low, in particular those in need because they are sick, old or vulnerable in other ways, application of this principle would imply that they would receive relatively little if anything. Many respond to this fact by claiming that need calls for a principle of just redistribution. Democratic Justice restricts justifiable redistribution to maintaining economic security across the life-cycle, with people meeting their needs by various forms of risk-pooling. It is this interpretation of the legitimate scope of redistribution that critics find unacceptable. Bufacchi, for example, asks why it is that producers are secure the full fruits of their labour, and Follesdal notes that in a market economy people may work for income net of anticipated taxation. From these perspectives there is no reason to assume that people are owed what they produce, particularly in the face of need.

Properly to evaluate these criticisms, we need to consider some qualifications to the full fruits and marginal product principles, together with an important methodological implication. Two principal qualifications to the full fruits principle are advanced in Democratic Justice. Firstly, entitlement depends upon everyone having roughly equal access to the means of production. Secondly, those producers make a contribution to the costs of providing public goods. These qualifications have important implications. The full fruits principle is often associated with libertarian accounts of the economic order in which the principle of justice is 
that whatever one secures through exchange in the market is properly one's own. Allocation in a market economy is then equated with the results of economic activity in what are called 'market economies' in the current capitalist order. So theorists infer what the results of applying the full fruits principle would be by observing the distribution of income and wealth as they occur in actually existing capitalist economies. It is this last equation that democratic contractarianism denies.

One reason for this denial is that the conditions qualifying the entitlement to income are not met. Access to the means of production is not equal and educational systems fail to develop human capital consistent with the principle of equality of opportunity. However, the principal reason why Democratic Justice denies that the allocative outcomes of modern capitalist economies conform to the principle of marginal productivity is the existence of hierarchies within firms by which workers are typically not paid their marginal product. I cite empirical evidence to this effect from the work of Robert Frank (1985) and note that Alfred Marshall was right many years ago in suggesting that the returns to a firm be regarded as 'composite quasi-rent' divided among different persons 'by bargaining, supplemented by custom and by notions of fairness' (Marshall, 1920: 520). In short the inequalities in returns to productive effort that one observes in modern capitalist societies are not a product of a simple application of the principle of marginal productivity and do not reflect differential productivity.

One of the reasons why Follesdal thinks that I err in respect of redistribution is that I do not pay enough attention to the role of the 'basic structure' of society - the ground rules that allocate rights and powers, burdens and benefits - on the prospects, abilities and aspirations of members of society. He suggests four ways in which consideration of the role of the basic structure would lead one to reject democratic contractarianism: common property resource regimes are institutions within the basic structure, and so cannot be used to model such a 
structure; the basic structure has pervasive and profound effects on individuals' life-chances; it also has profound effects on their aspirations; and, as a scheme of cooperation, it is the product of citizens' behaviour and so those citizens have common claims upon the benefits it produces.

Properly to consider all four of these arguments would take me way beyond my allotted word length. However, there are at least two counter-arguments to be noted. Firstly, it is often particular legal arrangements or public policies, rather than the basic structure, that are important in generating high returns that exceed marginal product. Follesdal's own example of slots for professional training is a case in point. Similarly, it is public policy decisions about intellectual property rights that have created software billionaires, who would not have secured such high returns had the software been open access. It is the sale of the rights to broadcast football matches on pay to view outlets that have raised footballers' incomes over and above what they would have been had the matches been broadcast free to air. It is the failure to regulate for the proper disclosure of fees that has meant that executives in financial services have very high incomes. Reform of these practices is not a matter of basic structure. Open source software, free to air sports broadcasts and transparency in contracts for financial services are all consistent with a constitutional recognition of a strong right to private property in a basic structure.

Secondly, there are limits as to what one can infer from the fact that the basic structure is product of social cooperation and economies of scale. Because it is social cooperation that makes individual productive effort possible, it is sometimes asserted that this gives a claim by the members of society on the fruits of the labour of any one of their members. For example, it provides the basis for the Rawlsian (Rawls, 1999: 87) claim that the distribution of natural talents is to be regarded as in some respects a common asset. However, it is this inference that Democratic Justice denies. The economies of scale that make individual activity highly 
productive provide the grounds for a claim by one individual upon the product of another. Consider, as an example, the change that takes place in productivity when a functioning electricity network is introduced into the economy. Such networks exemplify economies of scale. Once established, they allow people to work at times when natural light is unavailable and to use forms of writing and data storage that are fast and efficient. It does not follow from these facts that those who are prepared to work longer hours than others, or those who are more efficient in their use of time and materials have an obligation to share their higher returns with others.

Bufacchi looks at the problem from the opposite end of the spectrum focusing on the needs of the most vulnerable rather than the obligations of the more productive. In particular, he takes the example of the congenitally disabled who may have little capacity to work but who under the marginal product principle would have no claims in justice against those who were fitter or stronger. As a contractarian Gauthier also thought this was a problem but could see no way within his theory of dealing with the problem, and so he was prepared to say that there was no claim in justice by such persons (Gauthier, 1986: 268), a conclusion for which he has been criticised. However, in Democratic Justice I claim that there is no need for contractarians to make a rod for their own backs in this way. The congenitally disabled are born to someone in a particular place and time. The failure of justice to provide for their needs is a failure to institute a well-crafted scheme of social insurance that will make adequate provision, enable training and education and spread the burden, insofar as parents and carers experience it as a burden, of nurture and support.

Bufacchi characterizes this solution as turning the problem of injustice into a case of the 'mismanagement of risk', suggesting this as a shortcoming of the theory. However, I happily embrace this characterization. If we have learnt anything about the injustices associated with the location of hazardous facilities near residential areas, it is that planning and regulatory 
mismanagement are a potent expression of injustice, most recently seen in the chemical explosion in Tianjin in China in August 2015. Where mismanagement arises from negligence, it is a form of injustice.

In Democratic Justice I did not develop in detail the public policy implications of the principles of political economy that I would associate with democratic contractarianism. Indeed I am still working on the task. However, it may help readers to judge for themselves how far these implications are out of equilibrium with their considered judgements if I list the essential elements as I currently see them. On the principle of redistribution across the lifecycle, democratic contractarianism would give a high priority to early years' education and support for child-rearing including child and family benefits in the form of cash support. These benefits would be much higher than currently obtains in most capitalist welfare states, where in the last two decades the elderly have been over-generously treated. Mechanism of contributory social insurance would be in place to cover periods of sickness, accident, unemployment and retirement, although there would be no unconditional basic income. Policies would seek to spread asset ownership widely, but with restrictions on the premature sale of those assets. Taxation would fall on consumption, rather than income, and it would be levied on a progressive basis to economize on the use of resources. A land tax would reduce the pure rental gains that arise from property price inflation. Public transport would substitute for private transport to reduce the very considerable environmental externalities created by cars and goods transport on the roads. There would be as much of an open access regime in intellectual property rights, including pharmaceuticals, as was compatible with innovation at a respectable pace. And there would be some form of 'public trustee' model of ownership of the natural monopolies of the utilities, though this could be compatible with regulated private ownership. To my mind such policies would go far in slaying Beveridge's five giants of want, disease, squalor, ignorance and idleness, whilst allowing individuals and 
households to improve their own lives in their own way without a putative obligation in justice to improve the lives of others.

Andreozzi (2016) suggests that, if such a programme is the goal, then there is no need for public policy because private savings and insurance can accomplish much that is needed by way of risk reallocation across the life-cycle. To the extent to which this is true, there is no reason for the democratic contractarian to deny the claim, since there is no case for public action just for the sake of public action. However, market failure is pervasive in respect of life-time income spreading, as the literature on the economics of the welfare state has shown (nicely summarized in Barr, 2001). However nothing of deep theoretical interest, rather than practical policy, turns on these judgements about market failure. As a matter of principle, the democratic contractarian can concede the point that if markets can do the job, then there is a reasonable presumption that they should be allowed to do so. The issue is a pragmatic one as to what institutions work best to achieve the goals of economic security over the life-cycle, and a theoretical deduction has little to say in that regard.

However, behind Andreozzi's point about life-cycle redistribution, there is a larger and potentially more fundamental challenge to the methodological approach advocated by Democratic Justice, namely that the supposed advantage of being able to rely upon an empirical method of social contract analysis is undermined by all observation being theoryladen. There is no unvarnished news. Even empirical findings need to be interpreted in the light of a prior framework of understanding. To that claim I now turn.

\section{Empirical Contracts and Social Science Interpretation}

One of the main methodological ambitions of Democratic Justice was to offer a solution to a problem that has dogged modern social contract theory, namely its indeterminacy. In 
different contract theories, quite different principles of justice are suggested depending, for example, on whether the contracting parties are assumed to be Bayesian utility maximizers (Harsanyi, 1955, 1975a and 1975b), Rawlsian maximiners (Rawls, 1999: 130-9; 2001: 95104), Gauthierian maximin relative concession reasoners (Gauthier, 1986: 130-50) or Scanlon (1982) and Barry (1995) reasonable negotiators. Such theoretical indeterminacy is important because, as Rawls (1999: 30-6) continued to stress, one function of social contract theory is to offer a systematization of competing first-order principles in order to avoid the indeterminacy of ethical intuitionism. However, if seemingly small changes in the specification of the contractual situation can lead to mutually incompatible principles of justice, we have merely displaced the first-order controversy about principles of justice into a second-order problem of how to construct a plausible theoretical device of representation.

In Democratic Justice I took up Barry's (1989: 347-8) suggestion that instead of the a priori method of hypothetical contract theory, we could use an empirical method, animated by the thought that some actual societies may approximate more or less closely to the conditions under which an impartial agreement on terms of social and political organization would emerge. Barry subsequently suggested that these conditions were to be found 'in some of the smaller Western European countries such as the Netherlands and Scandinavia' (Barry, 1995: 106). Much as I admire the Netherlands and the Scandinavian countries, it seemed to me that there was something potentially circular in using these countries as models of a social contract when thinking about the justice of contemporary societies. By contrast, common property resource regimes occurred in many different cultural contexts and exhibited a logic in which, in situations of moderate scarcity, participants had to act both to further their common interests and to protect their separate interests.

Andreozzi objects to this selection of models, offering two alternatives, namely the governance of medieval markets by the guilds and the practices of hunter-gatherer societies. 
He suggests that if one were to focus on the medieval guilds, then the results would be more libertarian than the principles of Democratic Justice, whereas if one focused on huntergatherer societies, the results would be more egalitarian. Andreozzi notes that Bertram (2015) has already raised the model of hunter-gatherer societies, but he adds an important methodological twist. If the ambition of Democratic Justice was to avoid the circularity problem of a priori hypothetical contract theory, in which first-order disputes were merely transformed into second-order disagreements about theory construction, the empirical method threatens to reproduce the problem in a different form. Empirical evidence has to be interpreted, and different interpretations will suggest different principles of social order. Circularity has been recapitulated. We thus have two problems. On what basis should we choose our empirical models? And, even if we have chosen a model, how do we control for competing interpretations?

On the question of the choice of model, at one level I am quite relaxed about introducing different models into our normative theory, both to reflect the different specific problems of justice and governance that agents have to deal with and to ensure that purported solutions suit the circumstances of particular societies. As Follesdal notes, one of the consequences of the empirical method is to reverse the familiar strategy of starting with standards for the basic structure of society as a whole, then extrapolating those standards to particular domains of concern, whether the family or international relations. It follows from this reversal that circumstances matter. The analysis that Andreozzi presents of the medieval guilds, though distinct from the logic of common property resource regimes, is consistent with the logic of those regimes. In both the issue of compliance is dealt with by public monitoring of performance and there are mechanisms for the adjudication of disputes among participants. In the case of the medieval guilds, the credible threat of being able to move the location of the markets provided the guilds with some autonomy in their decision making in relation to 
potentially predatory town authorities, a feature that is consistent with the self-governing character of common property resource regimes.

However, the choice of common property regimes was not arbitrary, even if it is only the beginning of the use of the empirical method. Unlike the medieval guilds, resource management in common property resource regimes occurs in a given territorial area, whether that be grazing lands, forests, water resources or fishing grounds. In this respect, such regimes can provide a model for justice in the modern state, which by definition exercises authority within a given territorial area. Moreover, by contrast with hunter-gatherer societies that operate at the margin of subsistence, they are also found in circumstances of moderate scarcity, so satisfying one of Hume's conditions for the circumstances of justice.

I am sceptical that hunter-gatherer societies provide a generally more plausible model than common property resource regimes if the claim is based on the assertion that the latter are rare whereas as the former have 'remained stable over millennia' as Andreozzi puts it. If this is an evolutionary argument, then the unit of analysis ought to be individuals, and although hunter-gatherer societies lasted over millennia, a very high proportion of human individuals have lived since the invention of agriculture, say around 8000 BCE. The upper bound estimate given by the US Census Bureau for those alive in $5000 \mathrm{BCE}$ is 20 million people, and the lower bound is 5 million. This contrasts with somewhere between 2.4 and 2.5 billion people in 1950 , with the very dramatic rise coming since 1700. (See:

https://www.census.gov/population/international/data/worldpop/table_history.php). If we are going to use an evolutionary argument, it would seem more logical to look at the characteristics associated with this very rapid expansion in human numbers since the invention of agriculture. More generally, one should be cautious about the use of evolutionary genetics in explaining human social development, given that cultural change takes place more quickly than genetic change. 
However, this still leaves the methodological problem of interpretation, on which Andreozzi is very thought-provoking. Consider his example of two competing explanations for foodsharing in hunter-gatherer societies. In societies in which hunter-gatherers rely upon the killing of large animals, we can explain the practice of food-sharing either in terms of reciprocal altruism, in which the sharing is a form of mutual insurance, or in terms of tolerated theft, in which the sharing reflects the diminishing marginal utility of one hunter fighting off others. These distinct explanations would seem to map almost perfectly onto a social contract conceived in Rawlsian terms, in which reciprocity is the guiding value, and a social contract conceived in Buchanan terms, in which the contract is an equilibrium of predation and defence. What gain, then, from the empirical approach?

The right theoretical response here, I suggest, is to distinguish between the circumstances in which the sense of justice emerges and the conditions that sustain a social equilibrium once the sense of justice is in operation. Consider, for example, Rawls (1996: 159) discussion of the emergence of the doctrine of toleration as a result of the stalemate of the religious wars following the Reformation in Europe. Despite these origins, we would not expect the mutually beneficial equilibrium to be maintained unless the parties to a conflict had internalized the norms in such a way that they were motivated to follow those norms even when they could disregard them without penalty. The norm of reciprocity is the moralized counterpart to the equilibrium of strength.

\section{Conclusion}

Bufacchi thinks my focus on the political economy of justice ignores that dimension of justice that discusses recognition. It is certainly true that no attention in paid in Democratic Justice to issues of identity and recognition. However, is it the case that the theory cannot 
encompass this dimension of social interaction? Answering this question leads to one central issue in the whole approach concerning the phenomenology of justice.

In the final chapter of Democratic Justice I speculate on the thought that well-formed habits of the heart may provide a more secure foundation for justice than a calculating appreciation of the balance of power in society. Nevertheless, I continue to insist on the role that a balance of power among different social groups can have in promoting justice, accepting that occasions when a full balance of power exists are relatively rare. Groups secure recognition, as well as resources, when they can make themselves heard. There is no need to be dogmatic and assume that groups making themselves heard is always something requiring struggle and assertiveness. Perhaps on some occasions benevolent social planners will include the formerly excluded in policies and programmes for their benefit. However, it would be unwise for such groups to rely upon such noblesse oblige. The counterpart to equal power among different social groups is a democratic system open to the assertion of demands by those whose legitimate interests are being overlooked. A democratic conception of justice rests on the presumption that the most secure foundation of any group's interests rests upon the willingness of that group's members to assert their claims, sometimes noisily and with disruption. Justice may need to be seized rather than bestowed.

Is such an attitude, resting as it seems to on a competitive model of democracy compatible with the requirement that a sense of justice be widely shared in a society? The merit of a mutual advantage conception of the social contract is its acceptance of the persistence of social conflict together with an insistence that dealing with such conflicts is seldom a zerosum game. Of course, it may take creative imagination to see how solutions to collective action problems can be found to mutual gain among those otherwise at odds with one another. This is why practical rationality is required in politics, since such rationality is never purely instrumental but also includes the need to invent and devise political solutions. The 
task of dealing with social conflict is hard at the best of times. It is impossible if justice is not related to some elements of a common good that all can share. 


\section{References}

Andreozzi, Luciano (2016) 'Political Theory in Historical Context: Reflections on Democratic Justice and the Social Contract by Albert Weale', Critical Review of International Social and Political Philosophy. This issue.

Barr, Nicholas (2001) The Welfare State as Piggy Bank: Information, Risk, Uncertainty and the Role of the State (Oxford: Oxford University Press).

Barry, Brian (1989) Theories of Justice (London: Harvester-Wheatsheaf).

Barry, Brian (1995) Justice as Impartiality (Oxford: Oxford University Press).

Bertram, Chris (2015) 'On Albert Weale's “Full Fruits” Principle', Political Studies Review, 13: 2, pp. $217-25$.

Buchanan, James M. (1975) The Limits of Liberty: Between Anarchy and Leviathan (Chicago and London: University of Chicago Press).

Bufacchi, Vittorio (2016) 'Democratic Justice and Contractarian Injustice', Critical Review of International Social and Political Philosophy. This issue.

Castiglione, Dario (2015) 'The Logic of Cooperation for Mutual Advantage - The Democratic Contract', Political Studies Review, 13: 2, pp. 161-75.

Cordelli, Chiara (2015) 'Democratic Justice and the Boundaries Problem', Political Studies Review, 13: 2, pp. 196-206.

Denyer, Nicholas (1983) 'The Origins of Justice' in Giovanni Pugliese Carratelli (ed.),

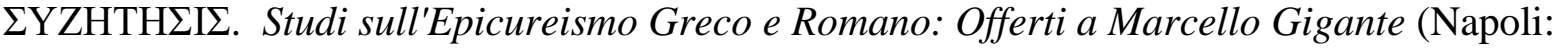
Gaetano Macchiaroli Editore), pp. 133-52. 
Follesdal, Andreas (2016) 'Getting to Justice?', Critical Review of International Social and Political Philosophy. This issue.

Frank, Robert H. (1985) Choosing the Right Pond: Human Behavior and the Quest for Status (New York and Oxford: Oxford University Press).

Gauthier, David (1986) Morals by Agreement (Oxford: Clarendon Press).

Gentile, Valentina (2016) 'Democratic Justice: The Priority of Politics and the Ideal of Citizenship', Critical Review of International Social and Political Philosophy. This issue.

Harsanyi, John C. (1955) 'Individualistic Ethics, and Interpersonal Comparisons of Utility', Journal of Political Economy, 63:4, pp. 309-21.

Hayek, F. A. (1973) Law, Legislation and Liberty, Volume 1, Rules and Order (London: Routledge).

Hobbes, Thomas (1651) Leviathan, edited with an introduction by Michael Oakeshott (Oxford: Basil Blackwell, n.d.).

Hohfeld, W.N. (1923) Fundamental Legal Conceptions (New Haven: Yale University Press). Howard, Jeffrey W. (2015) ‘The Instability of Democratic Contractarianism’, Political Studies Review, 13: 2, pp. 184-95.

Hume, David (1739/40) A Treatise of Human Nature, edited with an Introduction by Ernest C. Mossner (Harmondsworth: Penguin Books, 1969 edition).

Marshall, Alfred (1920) Principles of Economics, (London and Basingstoke: Macmillan, eighth edition reprinted 1979).

Matravers, Matt, (2000) Justice and Punishment: The Rationale of Coercion (Oxford: Oxford University Press). 
Matravers, Matt (2015) 'Justice and Constructivism', Political Studies Review, 13: 2, pp. $176-83$.

Mill, John Stuart (1869) The Subjection of Women, in On Liberty and Other Essays, edited with an Introduction by John Gray (Oxford: Oxford University Press, 1991), pp. 471-582.

Netting, Robert McC. (1981) Balancing on an Alp: Ecological Change and Continuity in a Swiss Mountain Community (Cambridge: Cambridge University Press).

O’Flynn, Ian (2015) 'Deliberative Democracy for A Great Society’, Political Studies Review, 13: 2, pp. 207-16.

Ostrom, Elinor (1990) Governing the Commons: The Evolution of Institutions for Collective Action (Cambridge: Cambridge University Press).

Ostrom, Vincent (2012) The Quest to Understand Human Affairs: Essays on Collective, Constitutional and Epistemic Choice, edited by Barbara Allen (Lanham: Lexington Books).

Plato, The Republic, translated Francis MacDonald Cornford (Oxford: Clarendon Press, 1941).

Rawls, John (1996) Political Liberalism (New York: Columbia University Press, paperback edition).

Rawls, John (1999) A Theory of Justice (Oxford: Oxford University Press, revised edition).

Rawls, John (2001) Justice as Fairness: A Restatement, edited by Erin Kelly (Cambridge, Mass.: The Belknap Press).

Scanlon, T.M. (1982) 'Contractualism and Utilitarianism’ in A. Sen and B. Williams (eds), Utilitarianism and Beyond (Cambridge: Cambridge University Press), pp.101-28. 
Smith, Adam (1776) An Enquiry into the Nature and Causes of the Wealth of Nations (Oxford: Clarendon Press, 1976 edition).

Weale, Albert (2013) Democratic Justice and the Social Contract (Oxford: Oxford University Press).

Zhichao, Tong (2015) 'Rawlsian Property-Owning Democracy: An American Historical Interpretation', American Political Thought 4: 2, pp. 289-310. 